Check for updates

New York

Cite this as: BMJ 2021;374:n1905 http://dx.doi.org/10.1136/bmj.n1905 Published: 28 July 2021

\title{
Covid 19: More US institutes, universities, and businesses make masks mandatory as cases rise sharply
}

\author{
Janice Hopkins Tanne
}

President Joe Biden is expected to announce on 29 July a requirement for federal government employees to be vaccinated or to be regularly tested for SARS-CoV-2 as the nation faces a surge in cases of the delta variant. Until now the president has hesitated to make vaccination mandatory because of opposition from conservatives, including many Republicans.

The Centers for Disease Control and Prevention said on 27 July that everyone, even fully vaccinated people, should wear masks in indoor spaces in hotspot areas for the virus. The CDC also called for children and teachers to wear masks when schools reopen. It said there was evidence that fully vaccinated people could nevertheless be infected with the highly transmissible delta virus and could spread it to unvaccinated people. ${ }^{1}$

About half the US population has been fully vaccinated, although there is great variation among the states, ranging from $67 \%$ in the northern state of Vermont to $34 \%$ in the southern states of Mississippi and Alabama. ${ }^{2}$

The federal government has about two million civilian employees. In addition, the armed forces have about 1.3 million people on active service and about 850 ooo in the reserves.

The huge Veterans Administration, which provides medical care to military veterans and their families, required all employees working in patient care to be vaccinated a few days ago. ${ }^{3}$

Many state and local governments, universities, hospitals, and healthcare systems and some private businesses have already begun requiring employees to show proof of vaccination or to undergo weekly testing for the virus.

The American Medical Association, the American Public Health Association, the American College of Physicians, and the American Academy of Pediatrics, and many other medical organisations have called for employers of healthcare workers, such as hospitals, clinics, and facilities caring for elderly people, to require their workers to be vaccinated.

Several large academic medical centres, including New York-Presbyterian and Yale-New Haven, have already required their healthcare workers to be vaccinated. New York City has required workers in its city run hospitals and clinics to be vaccinated or to have a weekly test.

The most populous state, California, will require its two million healthcare workers to be vaccinated or to undergo weekly testing, beginning next month.
Many large universities now require students to be vaccinated or have weekly tests. Indiana University, for example, with about 90 ooo students, has made vaccinations mandatory for students. The requirement was challenged in court, but a federal judge ruled that the requirement was constitutional. ${ }^{4}$

The financial firm Goldman Sachs has required its US employees to report their vaccine status. ${ }^{5}$

The federal Department of Justice issued a ruling saying that federal law does not forbid public agencies and private business from requiring vaccinations. ${ }^{6}$

New York City will require all one million students, and also teachers and staff, to wear masks when schools reopen in the autumn.

The national rise in covid-19 cases is due to the spread of the delta variant, especially among unvaccinated people in southern and central states such as Louisiana, Florida, Missouri, Arkansas, and Mississippi. The delta variant now causes about 83\% of cases nationally. Cases in Louisiana have risen from 400 cases a day at the beginning of July to more than 2400 cases a day now, the New York Times reported. ${ }^{2}$

Centers for Disease Control and Prevention. Covid-19: When you've been fully vaccinated. 27 Jul 2021. https://www.cdc.gov/coronavirus/2019ncov/vaccines/fully-vaccinated.html.

2 Corona virus in the US: latest map and case count. New York Times. 27 Jul 2021. https://www.nytimes.com/interactive/2021/us/covid-cases.html

3 Smith I. VA mandates covid vaccines for medical employees. Fedsmith. 27 Jul 2021. https://www.fedsmith.com/2021/07/26/va-mandates-covid-vaccines-medical-employees.

4 Anderson N. Federal judge upholds coronavirus vaccine for Indiana University students. Washington Post. 16 Jul 2021. https://www.msn.com/en-us/news/us/federal-judge-upholds-coronavirusvaccine-mandate-for-indiana-university-students/ar-AAMkOLX.

5 Hirsch L. Goldman Sachs requires its US employees to report their vaccine status. New York Times. 10 Jun 2021. https://www.ny-

times.com2021/06/10/business/goldman-sachs-vaccination-status.html.

6 Singman B. DOJ declares vaccine mandates legal. Fox News. 27 Jul 2021. https://www.foxnews.com/politics/doj-vaccine-mandates-legal.

This article is made freely available for use in accordance with BMJ's website terms and conditions for the duration of the covid-19 pandemic or until otherwise determined by BMJ. You may use, download and print the article for any lawful, non-commercial purpose (including text and data mining) provided that all copyright notices and trade marks are retained. 